\title{
The Effect of Shopping Lifestyle, Fashion Involvement and Sales Promotion on Positive Emotions
}

\author{
Laurra $^{1}$,Teddy Oswari ${ }^{2}$, Erni Hastuti ${ }^{3}$, Melvi Yansi ${ }^{4}$ \\ Faculty of Economics, Gunadarma University ${ }^{1,2}$ \\ Faculty of Letters and Culture, Gunadarma University ${ }^{3}$ \\ Faculty of Economics, Prof. University. Dr. Hazairin, SH Bengkulu ${ }^{4}$ \\ \{1aurraester@gmail.com ${ }^{1}$, toswari@staff.gunadarma.ac.id ${ }^{2}$, melviyansi2175@gmail.com $^{4}$ \}
}

\begin{abstract}
The purpose of this study was to determine the effect of Shopping Lifestyle, Fashion Involvement and Sales Promotion on Impulse Buying with Positive Emotion as an Intervening Variable in the Consumer of Bukalapak Online Shop in Bekasi. Data collection techniques with distributing questionnaires based on The maximum likelihood estimation (MLE) technique is 150 respondents. At the analysis stage, analysis of the validity and reliability test, normality test, Analysis of Structural Equation Model (SEM), Validity Test of Convergence, and Model Causality Test. The results showed thatShopping Lifestyle for Positive Emotion, Sales Promotion for Positive Emotion, Positive Emotion for Impulse Buying, Shopping Lifestyle for Impulse Buying through Positive Emotion and Sales Promotion for Impulse Buying through Positive Emotion are influential in this study. Meanwhile, the variable Fashion Involvement on Positive Emotion and Fashion Involvement on Impulse Buying through Positive Emotion had no effect in this study.
\end{abstract}

Keywords: Shopping Lifestyle; Fashion Involvement; Sales Promotion; Positive Emotion; Impulse Buying

\section{Introduction}

In today's modern era, business activities in Indonesia are growing rapidly. One of the factors is due to the existence of information technology in the form of the internet in various business activities that make it easier for us to reach consumers because there are no distance and time limitations. According toNielsen (2014) with the increase in internet users, this affects changes in purchasing behavior that are usually made offline to online purchases. The rapidity of internet users is a driving factor for the increase in transactions conducted electronically (E-commerce). According to wikipedia.org, E-Commerce or electronic commerce (English: electronic commerce or e-commerce) is the distribution, buying, selling,marketing goods and services through the system electronic as Internet or television.

GenerationYoung people prefer to shop at online stores because prices are more competitive, there is no need to come directly to the store, and the items purchased will be delivered to the buyer's place. These various conveniences make online stores more attractive than physical stores. This is what makes the growth of online stores increase rapidly. At the 
beginning of entering Indonesia, e-commerce was doubted by consumers because of its security system problems. Over time, e-commerce has improved and gained the trust of Indonesian consumers. E-commerce benefits both consumers and entrepreneurs because there is no need to rent a shop or a space where the rental price is increasing. Selling costs can be reduced and consumers get a more competitive price.

There are so many e-commerce service providers in Indonesia, one of them is Bukalapak. Bukalapak is one of the online shopping centers (online marketplace) in Indonesia (also known as online shop network) which is owned and operated by PT. Bukalapak. Bukalapak was founded on January 10, 2010 by Achmad Zaky, Nugroho Herucahyono, and Fajrin Rasyid in Bandung, West Java. Bukalapak sells a variety of necessities, from baby equipment, fashion, hobbies and collections, electronics, even e-vouchers and tickets. Bukalapak also works with peddlers who are verified as having an official brand and selling an original item called BukaMall which guarantees its completeness and availability of stock.

Developmentconsumer needs, especially fashion, is closely related to changes in shopping lifestyle patterns. The need for fashion stimulates someone to shop for fashion products in order to keep up with the latest fashion models so that a shopping lifestyle is formed in a person. In addition, by following a certain fashion style, a person can show their identity and social status. This shopping lifestyle is often used by consumers by making excessive purchases, high purchasing power, which is driven by stimuli and attractive offers by sellers.

Another factor that causes impulsive buying in fashion products is fashion involvement or fashion involvement. Fashion involvement is the degree to which consumers see consumption of clothing as the center of their life and as a meaningful and enjoyable activity. Consumers with high fashion involvement tend to think that consumption of fashion is closely related to self-confidence so that people are often asked for their opinion (regarding fashion) in their group. Fashion involvement can also lead to impulsive buying behavior (Jones, Reynolds Weun \& Beatty., 2003) and influencetaking someone's decisions when shopping.

\section{Research purposes}

Aim of this research are as follows:

a. Knowing the influence of Shopping Lifestyle on Positive Emotion on Bukalapak consumers in Bekasi.

b. Knowing the influence of Fashion Involvement on Positive Emotion on Bukalapak consumers in Bekasi.

c. Knowing the effect of Sales Promotion on Positive Emotion on Bukalapak consumers in Bekasi.

d. Knowing the effect of Positive Emotion on Impulse Buying on Bukalapak consumers in Bekasi.

e. Knowing the effect of Shopping Lifestyle on Impulse Buying through Positive Emotion on Bukalapak consumers in Bekasi.

f. Knowing the effect of Fashion Involvement on Impulse Buying through Positive Emotion on Bukalapak consumers in Bekasi.

g. Knowing the effect of Sales Promotion on Impulse Buying through Positive Emotion on Bukalapak consumers in Bekasi.

\section{Review the Library}




\subsection{Marketing}

Marketing is an integrated effort to combine strategic plans aimed at satisfying the needs and desires of consumers to obtain the expected benefits through the exchange or transaction process. The company's marketing activities must be able to provide satisfaction to consumers if they want to get good responses from consumers.

\subsection{Shopping Lifestyle}

Shopping lifestyledefined as behavior shown by customers in connection with a series of personal responses and opinions about product purchases (Cobb and Hoyer, 1986 in Tirmizi, et al., 2009: 524). Shopping lifestyle according to Betty Jackson in Japarianto (2011: 33), is an expression of lifestyle in shopping that reflects differences in social status.

\subsection{Fashion Involvement}

Fashion involvementis someone's involvement with a clothing product because of the need, interest and value of the product. Fashion involvement is closely related to consumer characteristics, knowledge about fashion and purchasing decisions. Indicators of fashion involvement according to Georgia Liapati (2015) include:

a. Always have one or more clothes in the latest style

b. One of the most important aspects of life and activities is to dress well

c. More concerned with the aspects of fashion rather than just comfort if you have to choose a fashion

\subsection{Sales Promotion}

Sales promotion is a method of various techniques that aim to achieve cost-effective sales, by adding value to products and services. Sales Promotion, consists of two dimensions related to money (monetary) and not related to money (non-monetary). According to (Gunawan Kwan, 2016) sales promotion indicators are as follows: Discount, Cash back, and Price package

\subsection{Positive Emotion}

Emotionis an effect of mood which is an important factor for consumers in purchasing decisions. Positive emotions are defined as moods that influence and determine the intensity of consumer decision making (Watson and Tellegen in Tirmizi 2009).

According to (Hetharie, 2012) indicators of positive emotions are as follows: Feelings of joy / joy, Feelings of pride, and Feelings of passion

\subsection{Impulse Buying}

According to (Rahmadi, 2014) impulse buying is a condition that occurs when individuals experience a sudden feeling of urgency that cannot be resisted. This tendency to buy spotan generally occurs when consumers believe that the action is normal. Impulse buying that occurs in consumers in general is that there are several products that have a lower price so that 
consumers are interested and don't need to think about calculating the costs incurred. According to (Artha \& Yudi, 2014; Putu \& Yuliartini, 2014) impulse indicators buyingis as follows :

a. I am a person who often shopped without a plan.

b. I find it difficult to control myself from the urge to buy when I see attractive offers.

c. The feeling of immediately having the product on offer.

d. There is an excessive feeling of interest in the products being offered.

\subsection{Framework}

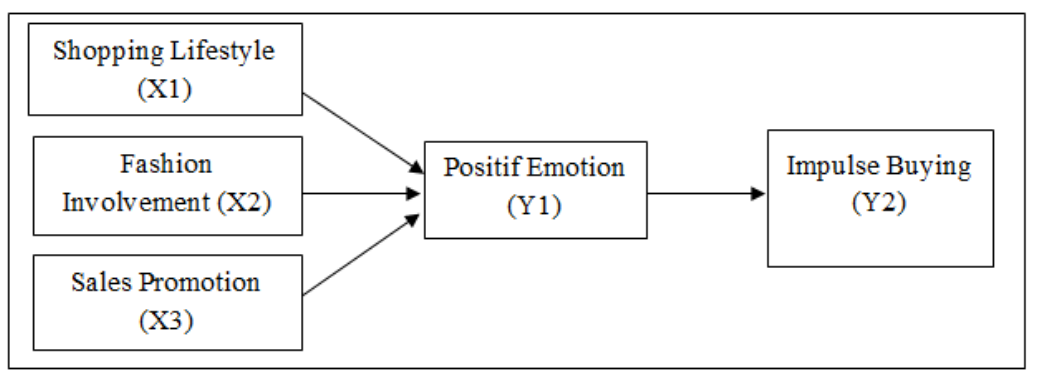

Fig. 1. Framework

\subsection{Research Hypothesis}

The hypotheses in this study are:

H1: There is an influence between the Shopping Lifestyle variable on Positive Emotion

$\mathrm{H} 2$ : There is an influence between the variable Fashion involvement on Positive Emotion

H3: There is an influence between the Sales Promotion variable on Positive Emotion

H4: There is an influence between the Positive Emotion variable on Impulse Buying

H5: There is an influence between Shopping Lifestyle variables on Impulse Buying through Positive Emotion

H6: There is an influence between the Fashion Involvement variable on Impulse Buying through Positive Emotion

H7: There is an influence between the Sales Promotion variable on Impulse Buying through Positive Emotion

\section{Research Methods}

\section{1 Object of Research}

The object of this research is the Bukalapak online shop. The subjects in this study were consumers or customers of Bukalapak online shop in Bekasi.

\subsection{Population}

The population in this study were all consumers or customers of Bukalapak online shop in Bekasi who had shopped for fashion products. 


\subsection{Sample}

The sampling technique used in this study is using non probability sampling using purposive sampling method. Size The sample that must be fulfilled in this modeling is to use a sample size in accordance with the maximum likelihood estimation (MLE) technique, which is 100-200 respondents (Ghozali 2008). So the research sample is 150 consumer respondents or customers of Bukalapak online shop in Bekasi City.

\subsection{Analysis Tools Used}

The analytical tools that I use in data processing are Likert scale, validity test, reliability test, and Structural Equation Model (SEM) analysis.

\section{Results and Discussion}

\subsection{Respondent Identification}

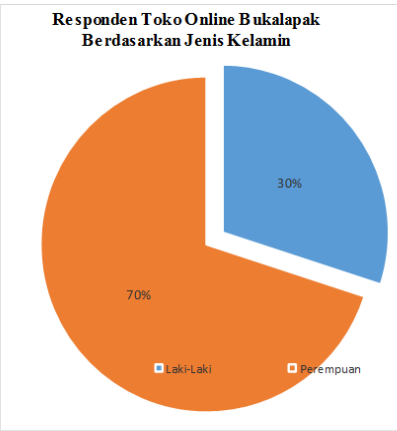

Fig. 2. Gender

Karakteristik Responden Berdasarkan Pendapatan

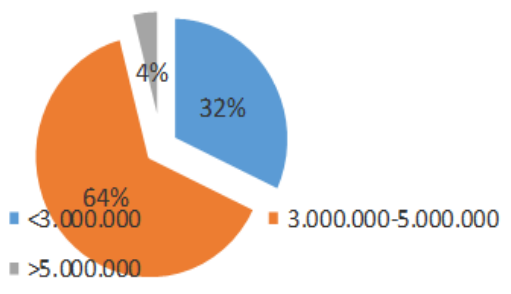

Fig. 4. Income

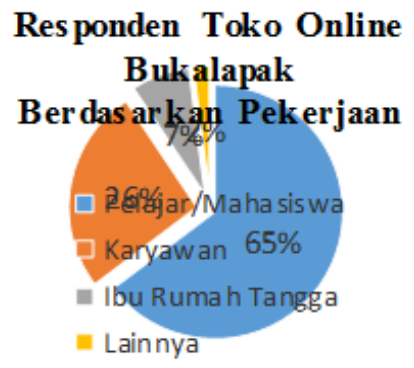

Fig. 3. Profession

Karakteristik Responden Berdasarkan Frekuensi Pembelian

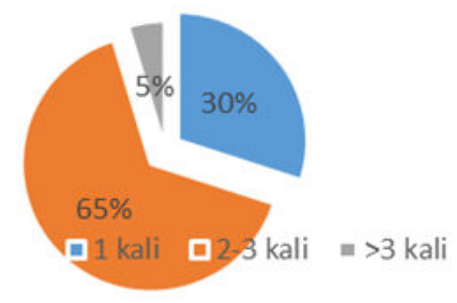

Fig. 5. Purchase Frequency

\subsection{Validity test}

According to Ghozali (2016) the questionnaire is declared valid if the statement on the 
questionnaire is able to reveal something that is measured by the questionnaire.

a. If $r$ count $>r$ table, then the statement is said to be valid.

b. If $r$ count $<r$ table, then the statement is said to be invalid.

If has been fulfilling these requirements, it can be concluded that the instrument has good construct validity and is suitable to be used as a research questionnaire.

Table 1. Validity Test Results

\begin{tabular}{cccc}
\hline Statement & Rhitung & r table & Information \\
\hline Shopping Lifestyle 1 & 0.574 & 0.1603 & Valid \\
Shopping Lifestyle 2 & 0.690 & 0.1603 & Valid \\
Shopping Lifestyle 3 & 0.678 & 0.1603 & Valid \\
Shopping Lifestyle 4 & 0.695 & 0.1603 & Valid \\
Shopping Lifestyle 5 & 0.595 & 0.1603 & Valid \\
Shopping Lifestyle 6 & 0.548 & 0.1603 & Valid \\
Fashion Involvement 1 & 0.767 & 0.1603 & Valid \\
Fashion Involvement 2 & 0.743 & 0.1603 & Valid \\
Fashion Involvement 3 & 0.740 & 0.1603 & Valid \\
Sales Promotion 1 & 0.701 & 0.1603 & Valid \\
Sales Promotion 2 & 0.654 & 0.1603 & Valid \\
Sales Promotion 3 & 0.688 & 0.1603 & Valid \\
Sales Promotion 4 & 0.573 & 0.1603 & Valid \\
Positive Emotion 1 & 0.734 & 0.1603 & Valid \\
Positive Emotion 2 & 0.877 & 0.1603 & Valid \\
Positive Emotion 3 & 0.676 & 0.1603 & Valid \\
Impulse Buying 1 & 0.857 & 0.1603 & Valid \\
Impulse Buying 2 & 0.860 & 0.1603 & Valid \\
Impulse Buying 3 & 0.748 & 0.1603 & Valid \\
Impulse Buying 4 & 0.679 & 0.1603 & Valid \\
\hline
\end{tabular}

Based on the results of the validity test, it is known that all statement items in this study are valid or also called all relevant statements, indicated by the value of each statement item that has a positive value and is greater than the $r$ value of the table, namely 0.1603 .

\subsection{Reliability Test}

Reliability test is a tool for measuring a questionnaire which is an indicator of a variable or construct. A construct or variable is said to be reliable if it gives a Cronbach Alpha value $\geq$ 0.60 (Nunnallly in Ghozali, 2012).

Table 2. Reliability Test Results

\begin{tabular}{llll}
\hline Variable & Cronbach's Alpha & Alpha Value Limits & Information \\
\hline Shopping Lifestyle (X1) & 0.752 & 0.60 & Reliable \\
Fashion Involvement (X2) & 0.800 & 0.60 & Reliable \\
Sales Promotion (X3) & 0.754 & 0.60 & Reliable \\
Positive Emotion (Y1) & 0.811 & 0.60 & Reliable \\
Impulse Buying (Y2) & 0.811 & 0.60 & Reliable \\
\hline
\end{tabular}

Based on table 2, the reliability test results show that all statement items in this study are reliable because they have a Cronbach's Alpha value above 0.60.

\subsection{Analysis of Structural Equation Model (SEM)}




\section{a) Creating a Path Diagram}

SEM models can be represented in mathematical equations or path diagrams. Path diagram is a visual representation of a model that describes all the relationships between the variables in it. Therefore, the use of a path diagram can make it easier to see the relationships that exist in the model.

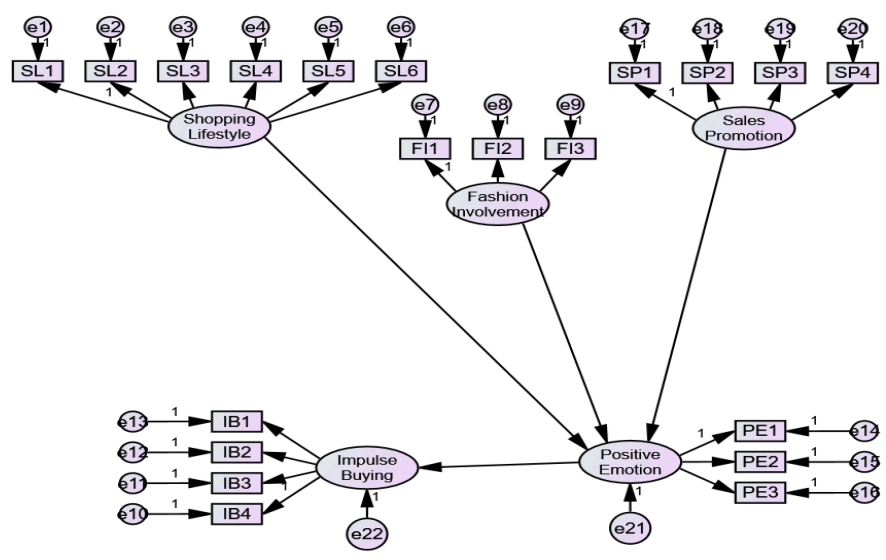

$$
\begin{aligned}
& \text { Chi-square }=\text { lcmin } \\
& \text { Probability }=\backslash \mathrm{p} \\
& \text { CminDF }=\mathrm{cm}_{\mathrm{cm}} \mathrm{inF} \\
& \text { df }=\text { ldf } \\
& \mathrm{GFI}=\text { Igfi } \\
& \mathrm{AGFI}=\text { lagfi } \\
& \text { TLI }=\text { Itli } \\
& \text { CFI }=\text { Icfi } \\
& \text { RMSEA }=\text { Irmsea }
\end{aligned}
$$

Fig. 6. Path Diagram

The path diagram can be explained as follows:

1. There are 5 latent variables, namely Shopping Lifestyle, Fashion Involvement, Sales Promotion, Positive Emotion and Impulse Buying.

2. Shopping Lifestyle latent variable has 6 statement indicators, Fashion Involvement latent variable has 3 statement indicators, Sales Promotion latent variable has 4 statement indicators, Positive Emotion latent variable has 3 statement indicators, and Impulse Buying latent variable has 4 statement indicators.

3. There are 20 measurement errors, namely e1-e20.

4. There are 2 residual errors, namely e 21 and e 22.

5. It is assumed that the Shopping Lifestyle, Fashion Involvement, and Sales Promotion variables affect the Positive Emotion and Impulse Buying variables.

\section{b) Identifying the Model}

SEM analysis can only be done if the results of the model identification are included in the over-identified category. This identification is done by looking at the df (degree of freedom) value of the model that has been made. 
Table 3. Computation of degrees of freedom (Default Model)

\begin{tabular}{ll} 
Number of distinct sample moments: & 210 \\
Number of distinct parameters to be estimated: & 44 \\
Degrees of freedom $(210-44):$ & 166 \\
\hline
\end{tabular}

The resulting df (degree of freedom) value is 166. This explains that the model that has been made is in the over-identified category because it has a positive df value. Furthermore, data analysis can be continued to the next stage.

\section{c) Evaluating the Model}

The evaluation carried out on the model includes:

1. Sample size. The sample size that must be met in this modeling is to use a sample size that is in accordance with the maximum likelihood estimation (MLE) technique, which is 100-200 respondents (Ghozali 2008). In this study using a sample size of 150 respondents. So, the sample size in this study has met the predetermined requirements.

2. Data normality. Estimatewith Maximum Likelihood requires the observed variable to fulfill the assumption of multivariate normality. Therefore it is necessary to test to see the level of normality in a multivariate manner to the data used in this study. Evaluation of multivariate normality with AMOS 24.00 was carried out using the criterion of the critical ratio (cr) of multivariate for kurtosis, if it is in the range of \pm 2.58 , it means that the data is normally distributed multivariate. The results of data normality testing in this study indicate that the cr value for multivariate is 2,319 (can be seen in the appendix) between \pm 2.58 , so it can be concluded that the data is multivariate normally distributed.

3. Data Outliers. Outlier is a condition of observation of data that has unique characteristics that look very different from other observations and appear in the form of extreme values, both for single and combined variables. The detection of multivariate outliers was carried out by taking into account the value of Mahalanobis Distance. Mahalanobis Distance for each observation will show the distance of a data observation to its mean value (centroid). Observations of data that are far from their centroid values are considered outliers and should be removed (dropped) from the analysis. The criteria used are based on the Chi-Squares value at 20 degrees of freedom, namely the number of indicators in the fit of this research model at a significance level of $p \leq 0.001$. Mahalanobis Distance value using the formula CHII $(0.001 .20)=45,314$. This means that all cases (observation numbers) that have Mahalanobis d-squared values greater than 45,314 are multivariate outliers. The result of Mahalanobis Distance calculation in this research model (can be seen in the attachment) shows that all data observations have a Mahalanobis d-squared value below 45,314, which means that the research data used has met the requirements there are no multivariate outliers.

d) Testing the Feasibility of the Model (Goodness of Fit Test)

Table 4. Goodness of Fit Test

\begin{tabular}{clcc}
\hline $\begin{array}{c}\text { Criteria } \\
\text { (GOF) }\end{array}$ & \multicolumn{1}{c}{$\begin{array}{c}\text { Cut off Value } \\
\text { (Value Limit) }\end{array}$} & $\begin{array}{c}\text { Model Value } \\
\text { Research }\end{array}$ & Information \\
\hline \multirow{2}{*}{ AGFI } & $>0.9$ or & 0.784 & Poor Fit \\
\multirow{2}{*}{ TLI } & $\begin{array}{l}0.80<\mathrm{AGFI}<0.90 \\
>0.90 \text { or } \\
0.8<\mathrm{TLI}<0.90\end{array}$ & 0.766 & Poor Fit \\
\hline
\end{tabular}




\begin{tabular}{llcc}
\hline $\begin{array}{c}\text { Criteria } \\
\text { (GOF) }\end{array}$ & \multicolumn{1}{c}{$\begin{array}{c}\text { Cut off Value } \\
\text { (Value Limit) }\end{array}$} & $\begin{array}{c}\text { Model Value } \\
\text { Research }\end{array}$ & Information \\
\hline CFI & $>0.90$ or & 0.795 & Poor fit \\
RMSEA & $0.80<$ CFI $<0.90$ & 0.080 & Good fit \\
\hline
\end{tabular}

The model feasibility test (Goodness of Fit Test) is conducted to find out how fit the model is with the research data.

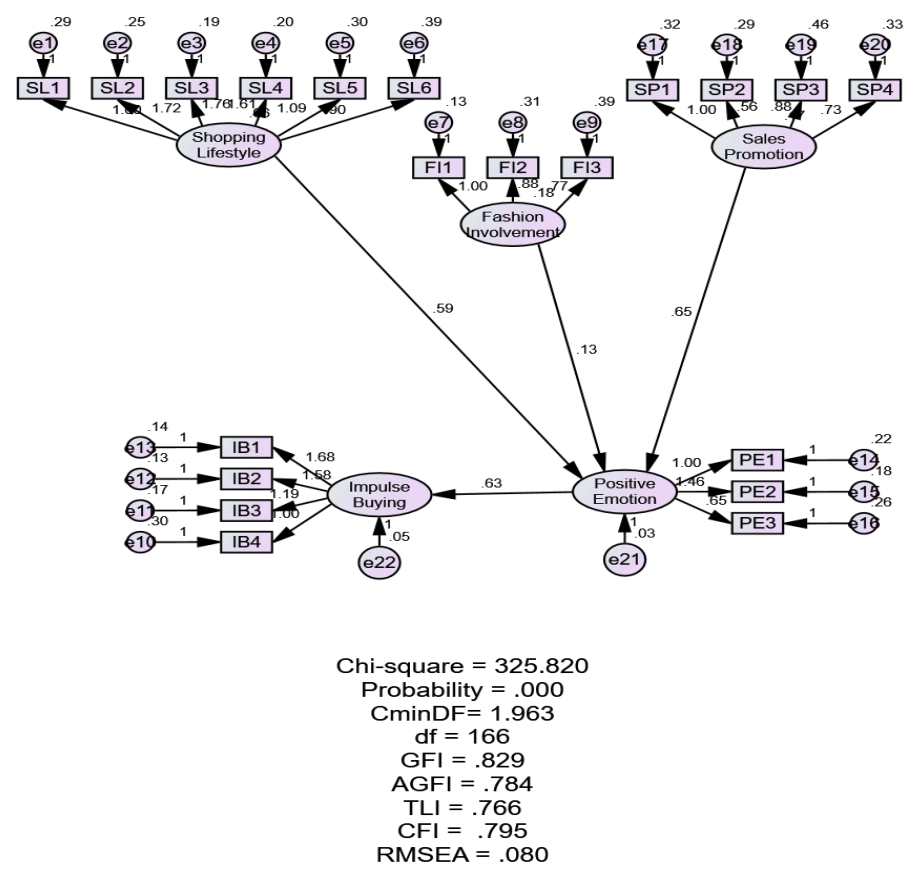

Fig. 7. Structural Model

Based on the output path diagram above, a summary of the results of the model feasibility test (Goodness Of Fit Test) is made:

Table 5. Results of the Initial Model Goodness Of Fit Test

\begin{tabular}{cccc}
\hline $\begin{array}{c}\text { Criteria } \\
\text { (GOF) }\end{array}$ & $\begin{array}{c}\text { Cut off Value } \\
\text { (Value Limit })\end{array}$ & $\begin{array}{c}\text { Model Value } \\
\text { Research }\end{array}$ & Information \\
\hline CHI-SQUARE $(\chi 2)$ & $<197.06391$ & 325,820 & Poor fit \\
$(\mathrm{df}=166, \mathrm{p}=0.05)$ & $<2.0$ & 1,963 & Good fit \\
$\mathrm{CMIN} / \mathrm{DF}$ & $\begin{array}{c}>0.90 \text { or } \\
\text { GFI }\end{array}$ & $0.80<\mathrm{GFI}<0.90$ & Marginal fit \\
\hline \multicolumn{4}{c}{ Source: Data processed from the results of AMOS 24}
\end{tabular}

Based on table 4, it shows that from the default model the values of Chi-Square, AGFI, TLI and CFI can be said to be Poor Fit, while the GFI values can be said to be Marginal Fit, and the values of CMIN / DF and RMSEA are said to be Good Fit because they meet the requirements according to the cut off value. . 


\subsection{Model Modification}

If the model does not fit the data, steps that can be taken include: Modify the model by adding or removing connections / links, Adding variables if data is available, and Reduce variables. Model modifications carried out in this study are based on the theory described in Ghozali (2014) that model modification can be done by looking at the table modification indices. If the model does not fit the data, the model modification is carried out to reduce the Chi-Square value so that the model becomes more fit.

Based on the output diagram contained in the attachment, a summary of the results of the Goodness of Fit test is made after being modified, the results can be seen in table 5 below:

Table 6. Modified Goodness of Fit Test Results

\begin{tabular}{|c|c|c|c|}
\hline Criteria (GOF) & $\begin{array}{c}\text { Cut of Value } \\
\text { (Value Limit) }\end{array}$ & $\begin{array}{l}\text { Model Value } \\
\text { Research }\end{array}$ & Information \\
\hline $\begin{array}{l}\text { CHI-SQUARE }(\chi 2) \\
(\mathrm{df}=138, \mathrm{p}=0.05)\end{array}$ & $<166.4152989$ & 138,808 & Good Fit \\
\hline $\mathrm{CMIN} / \mathrm{DF}$ & $<2.0$ & 1,006 & Good Fit \\
\hline GFI & $\begin{array}{l}>0.90 \text { or } \\
0.80<\mathrm{GFI}<0.90\end{array}$ & 0.919 & Good Fit \\
\hline AGFI & $\begin{array}{l}>0.9 \text { or } \\
0.80<\mathrm{AGFI}<0.90\end{array}$ & 0.877 & Marginal fit \\
\hline TLI & $\begin{array}{l}>0.90 \text { or } \\
0.8<\mathrm{TLI}<0.90\end{array}$ & 0.999 & Good Fit \\
\hline CFI & $\begin{array}{l}>0.90 \text { or } \\
0.80<\mathrm{CFI}<0.90\end{array}$ & 0.999 & Good Fit \\
\hline RMSEA & $<0.08$ & 0.006 & Good Fit \\
\hline
\end{tabular}

Based on the results of the model feasibility test (Goodness Of Fit Test), of the 7 criteria tested, 6 of these criteria are categorized as good fit. Meanwhile, AGFI is included in the Marginal Fit, which is quite feasible. Thus it can be said that the model is acceptable and there is a match between the model and the data.

\subsection{Hypothesis test}

The causality test aims to determine the causal relationship between exogenous and endogenous variables in a study. Besides that, it can also answer the research hypothesis. Hypothesis testing is performed using the t-value with a significance level of 0.05 . The $t$-value in the AMOS 24 program is the Critical Ratio (CR) value for Regression Weights. If the Critical Ratio $(\mathrm{CR})$ value $\geq 1.967$ or the probability value $(\mathrm{P}) \leq 0.05$ then $\mathrm{H} 0$ is rejected and the research hypothesis is accepted. The results of testing all the hypotheses proposed in this study are as follows:

Table 7. Regression Weights

\begin{tabular}{lclccccc}
\hline & & & Estimate & SE & CR & P & Label \\
\hline PositiveEmotion & $<-$ & Fashion Involvement & -206 & 0.153 & $-1,346$ & .178 & \\
PositiveEmotion & $<-$ & Sales Promotion & .657 & 0.138 & 4,765 & $* * *$ & \\
PositiveEmotion & $<-$ & Shopping Lifestyle & .782 & 0.240 & 3,263 & 0.001 & \\
ImpulseBuying & $<-$ & Positive Emotion & .634 & 0.131 & 4,848 & $* * *$ & \\
\hline
\end{tabular}

Source: Data processed from the results of AMOS 24 
1. Hypothesis 1, Table 7 shows that the t-value or $\mathrm{CR}$ is $3,263>1,967$ and the $\mathrm{P}$ value is $0.001<0.05$, then $\mathrm{H} 1$ is accepted, so it can be concluded that Shopping Lifestyle has a significant effect on Positive Emotion. The estimated value between the Shopping Lifestyle variable and Positive Emotion is 0.782 , which means that if the influence of Shopping Lifestyle has increased by 1, then Positive Emotion will also increase by 0.782 .

2. Hypothesis 2, Table 7 shows that the t-value or CR is $-1,346<1,967$ and the $P$ value is $0.178>0.05$, then $\mathrm{H} 1$ is rejected and $\mathrm{H} 0$ is accepted, so it can be concluded that Fashion Involvement has no significant effect on Positive Emotion. The estimate value between the Fashion Involvement variable and the Positive Emotion variable is -0.206 , which means that if the influence of Fashion Involvement has increased by 1, then Positive Emotion will also decrease by -0.206 .

3. Hypothesis 3, Table 7 shows that the t-value or CR is $4,765>1,967$ and there is a *** sign in the $\mathrm{P}$ value so $\mathrm{H} 1$ is accepted, so it can be concluded that Sales Promotion has a significant effect on Positive Emotion. The estimated value between the Sales Promotion variable and Positive Emotion is 0.657, which means that if the effect of Sales Promotion has increased by 1 , then Positive Emotion will also increase by 0.657 .

4. Hypothesis 4, Table 7 shows that the t-value or CR is $4,848>1,967$ and there is a *** sign in the P value so H1 is accepted, so it can be concluded that Positive Emotion has a significant effect on Impulse Buying. The estimated value between Positive Emotion and Impulse Buying is 0.634, which means that if the effect of Positive Emotion has increased by 1 , then Impulse Buying will also increase by 0.634 .

5. Hypothesis 5, Table 7 shows that the t-value or $\mathrm{CR}$ is $3,263+4,848=8,111>1,967$ and the $\mathrm{P}$ value is $0.001+0.001=0.002<0.05$, so $\mathrm{H} 1$ is accepted, so it can be concluded that Shopping Lifestyle has a significant effect on Impulse Buying through Positive Emotion. The estimated value between the Shopping Lifestyle variable and Impulse Buying through Positive Emotion is $0.782+0.634=1.416$, which means that if the influence of Shopping Lifestyle has increased by 1, then Impulse Buying through Positive Emotion will also decrease by 1.416 .

6. Hypothesis 6, Table 7 shows that the t-value or $\mathrm{CR}$ is $-1,346+4,848=3,502>1,967$ and the $\mathrm{P}$ value is $0.178+0.001=0.179>0.05$ then $\mathrm{H} 1$ is rejected and $\mathrm{H} 0$ is accepted, so it can be concluded that Fashion Involvement has no significant effect on Impulse Buying through Positive Emotion. The estimated value between the Fashion Involvement variable and Impulse Buying through Positive Emotion is $-0.206+0.634=0.428$, which means that if the influence of Fashion Involvement has increased by 1, then Impulse Buying through Positive Emotion will also increase by 0.428 .

7. Hypothesis 7, Table 7 shows that the $\mathrm{t}$-Value or CR value is $4,765+4,848=9,613>$ 1,967 and the $\mathrm{P}$ value is $0.001+0.001=0.002<0.05$ then $\mathrm{H} 1$ is accepted, so it can be concluded that Sales Promotion has a significant effect on Impulse Buying through Positive Emotion. The estimated value between the Sales Promotion variable and Impulse Buying through Positive Emotion is $0.657+0.634=1.291$, which means that if the effect of Sales Promotion has increased by 1, then Impulse Buying through Positive Emotion will also increase by 1.291.

\subsection{Discussion Analysis}

a) The Influence of Shopping Lifestyle on Positive Emotion 
The results showed that Shopping Lifestyle had a significant effect on Positive Emotion. Shopping lifestyle according to Betty Jackson in Japarianto (2011), is an expression of lifestyle in shopping that reflects differences in social status. Shopping lifestyle refers to consumption patterns that reflect one's choices about how to spend time and money. A consumer will have a positive mood because he is motivated to satisfy himself with fashion products. So thatThe feeling of joy or excitement that consumers feel when shopping can be felt when shopping at the Bukalapak online shop. Result research is supported by previous research conducted by Nurul Tri Rahmawati (2018) which states that Shopping Lifestylepositive and significant effect on positive emotions. So, it can be concluded that the Shopping Lifestyle variable indicator can support consumers in Positive Emotion.

\section{b) The Influence of Fashion Involvement on Positive Emotion}

The results showed that Fashion Involvement had no significant effect on Positive Emotion. This is because there are many productsotheroutside of fashion products that can cause positive emotions in themselves. For example, sports products (sports), electronics, beauty and care products, and other products offered by Bukalapak. So that consumers are not only focused on shopping for fashion products. The results of this study are different from previous studies conducted by Kiki Andani \& Wahyono Wahyono (2018) which states that Fashion Involvement has an effect on positive emotions. The absence of influence on the Fashion Involvement variable indicates that the indicator "I place importance on how I dress by buying fashion products at Bukalapak and I prefer to buy fashion products that are trending at Bukalapak". So, it can be concluded that the Fashion Involvement variable indicator cannot support consumers in Positive Emotion.

\section{c) The Effect of Sales Promotion on Positive Emotion}

The results showed that Sales Promotion had a significant effect on Positive Emotion. This is because the better the prices given through sales promotions such as discounts (discount), cashback promos, attractive price packages and the existence of free postage vouchers (postage) on fashion products at Bukalapak will cause positive emotions to consumers. This is supported by research Rizal Ahmad Alfarizi, N. Rachma, M. Hufron (2019) which states that sales promotions have a positive and significant effect on positive emotions. So it can be concluded that the Sales Promotion indicator supports consumers in Positive Emotion.

\section{d) The Effect of Positive Emotion on Impulse Buying}

The results showed thatPositive Emotion has a significant effect on Impulse Buying. This is because consumers do not have to bother visiting stores to buy these fashion products. One of the things that can be enjoyed in online shopping is that it can be done anywhere and anytime. In addition to the many choices, shopping at the Bukalapak online shop also tends to be cheap because sellers don't need to think about the cost of renting a place. The results of this study are supported by previous research conducted by Kiki Andani \& Wahyono Wahyono (2018) who stated thatpositive emotions influence impulsive buying. So, it can be concluded that the Positive Emotion variable indicator can support consumers in Impulse Buying.

e) The Influence of Shopping Lifestyle on Impulse Buying through Positive Emotion 
The results showed that Shopping Lifestyle had a significant effect on Impulse Buying through Positive Emotion. Shopping lifestyle is a lifestyle that refers to how a person lives, how they spend their time, money, buying activities, their attitudes and opinions about the world in which they live (Levy 2009 in Nurul Tri Rahmawati 2018). A consumer will have a positive mood because he is motivated to satisfy himself with fashion products so that consumers are used to make excessive and unplanned purchases. The results of this study are supported by previous research conducted by Nurul Tri Rahmawati (2018) which states that Shopping Lifestyle affects Impulse Buying through positive emotions. So it can be concluded that Indicators of Shopping Lifestyle variables can support consumers in Impulse Buying through Positive Emotion.

\section{f) The Influence of Fashion Involvement on Impulse Buying Through}

The results showed that Fashion Involvement had no significant effect on Impulse Buying through Positive Emotion. This matterbecausethe tendency to meet fashion needs stimulates a person to shop for fashion products impulsively in order to keep up with the latest fashion models. However, because of the many product categories offered by Bukalapak, it makes consumers not only buy fashion products so that positive emotions felt by consumers can also arise when consumers buy products outside of fashion products.

The results of this study are different from previous studies conducted by Juan Brundi Sarmento Madelra (2018) who states that positive emotions mediate the influence of Fashion Involvement on impulsive purchases of fashion products. So it can be concluded that The Fashion Involvement variable indicator cannot support consumers in Impulse Buying through Positive Emotion.

\section{g) The Effect of Sales Promotion on Impulse Buying through Positive Emotion}

The results showed that the Sales Promotion had an effect significantagainst Impulse Buying through Positive Emotion. According to Dawson \& Kim (2009) discounts and bonuses are the most dominant sales promotions used in online and offline sales. The better the price given, the consumer will feel positive emotions. Positive feelings mean as a positive influence, which reflects the extent to which a person feels enthusiastic, active, and alert, positive consumer emotions are related to the impulse to buy impulsively (Beatty and Ferrel, 1998 in Marie and Victor, 2014).

This is supported by research conducted by Kiki Andani \& Wahyono Wahyono (2018)which states that Sales Promotion has an effect on Impulse Buying through Positive Emotion. So, it can be concluded that the Sales Promotion variable indicator can support consumers in Impulse Buying through Positive Emotion.

\section{Closing}

\subsection{Conclusion}

Based on the results of the research on the questionnaire of 150 respondents that the researcher has conducted on consumers of Bukalapak online shop in Bekasi on Impulse Buying through Positive Emotion using a Likert Scale and Validity Test, Reliability Test, 
Structural Equation Model Analysis (SEM), the following conclusions are obtained:

a. Shopping Lifestyle effect on Positive Emotion

b. Fashion Involvement has no effect on Positive Emotion

c. Sales Promotion effect on Positive Emotion

d. Positive Emotion affect Impulse Buying

e. Shopping Lifestyle affect Impulse Buying through Positive Emotion

f. Fashion Involvement has no effect on Impulse Buying through Positive Emotion

g. Sales Promotion affect Impulse Buying through Positive Emotion

\subsection{Suggestion}

Based on the conclusions obtained in this study, suggestions are proposed for the research results as follows:

a. For further researchers, it is hoped that they can research with variables outside the variables that have been studied in order to obtain results that can affect Impulse Buying with Positive Emotion as an Intervening variable.

b. Companies must be able to improve fashion products in terms of quality, trends, fashions and more diverse brands so that consumers have more choices in shopping. Companies must also be able to provide fashion products with the latest models but still prioritize comfort in dressing for their consumers. So that from the availability of products that are diverse and comfortable to wear, it will cause positive emotions that can encourage consumers to make impulsive purchases.

\section{References}

[1] Alfarizi, Rizal Ahmad \& N. Rachma, M. Hufron. "The Effect of Sales Promotion and Store Atmosphere on Impulsive Purchasing with Positive Emotions as an Intervening Variable to Consumers of Superindo Tlogomas Malang.". Journal.University Of islam.

[2] Andani, Kiki \& Wahyono Wahyono. "The Effect of Sales Promotion, Hedonic Shopping Motivation, and Fashion Involvement on Impulsive Buying through Positive Emotions as Intervening variables". Semarang State University.

[3] Andani, Kiki. "Influence of Sales Promotion, Hedonic Shopping Motivation and Fashion Involvement Toward Impulse Buying through a Positive Emotion". Semarang State University.

[4] Assauri, Sofjan. 2015. Marketing Management: Basics, Concepts, and Strategies. Jakarta: PT Raja Grafindo Persada.

[5] Bong Soeseno. (2011). The Influence of In-Store Stimuli on Impulse Buying Behavior of Hypermarket Consumers in Jakarta, Ultima Management Vol. 3 No. 1 / 201131-52.

[6] Darma, LA, and Japarianto, E. (2014). Analysis of the Effect of Hedonic Shopping Value on Impulse Buying with Shopping Lifestyle and Positive Emotion as Intervening Variables at Mall Ciputra World Surabaya. Journal of Marketing Management. Vol. 8, No.2: 80-89.

[7] Dawson, S. and Kim, M., 2009. External and internal trigger cues of impulse buying. An International Journal. Vol. 3 No. 1, 2009 pp. 20-34.

[8] Diah, Ahyar Muhammad, Heldina Pristanti, Reni Aspianti, Syachrul. "The Influence of Hedonic Shopping Value and Store Atmosphere and Promotion of Impulse Buying through Positive Emotion on the consumer of Sogo Department Store in Samarinda". 
State Polytechnic of Samarinda.

[9] G. Muruganantham \& Bhakat, Ravi Shankar. "Review of Impulse Buying", International Journal of Marketing Studies; Vol. 5, No. 3; 2013.

[10] Ghozali, Imam. (2008). Structural Equation Modeling, Edition II, Diponegoro University, Semarang.

[11] Ghozali, Imam. 2016. Multivariate Analysis Application with IBM SPSS 20 Program. Publisher Diponegoro University. Semarang.

[12] Hapsari, Tiwi Siska. "The Effect of Sales Promotion and Store Environment on Impulse Buying with Positive Emotions as an Intervening Variable for Matahari Department Store Consumers". Surakarta State Islamic Institute.

[12] Hetharie, JA (2012). The Role of Positive Emotions as a Mediator of Store Environment Stimulus and Social Factors on Impulse Buying Tendency at Matahari Department Store, Ambon City. Journal of Management Applications, 4 (10).

[13] Japarianto, E., and Sugiharto, S. 2011. Influence of Shopping Lifestyle and Fashion Involvement on Impulse Buying Behavior of High Income Community Surabaya, Journal of Marketing Management, Vol. 6, No. 1, April: pp 32-40.

[14] Jones, MA, Reynolds, KE, Weun, S. and Beatty, SE (2003). The-product-specific nature of impulse buying tendency. Journal of Business Research, vol. 56, no. 7, pp. 501-511.

[15] Kotler, Philip and Kevin Lane Keller, (2016). Marketing Management, 15th Edition, Pearson Education, Inc.

[16] Kurniawan, Denny., \& Yohanes Sondang Kunto. (2013). The Influence of Promotion and Store Atmosphere Impulse Buying with Shopping Emotion as Intervening Variable Case Study at Matahari Department Store Supermall Surabaya Branch, 1 (2), 1-8.

[17] Kwan, Oky Gunawan. (2016). The Effect of Sales Promotion and Store Atmosphere on Impulse Buying with Positive Emotion as an Intervening Variable at Planet Sports Tunjungan Plaza Surabaya. Journal of Marketing Management, Vol. 10, No. 1, April 2016. ISSN 1907-235X.

[18] Liapati, Georgia., Assiouras, Ioannis., And Decaudin Jean-Marc. 2015. The Role of Fashion Involvement, Brand Love And Hedonic Consumption Tendency in Fashion Impulse Purchasing. Journal of Global Fashion Marketing, Vol. 6 No.4, pp. 251-264.

[19] Madelra, Juan Brundi Sarmento. "The Influence of Fashion Involvement on Impulsive Purchases in Fashion Products Mediated by Positive Emotions". Essay. Sanata Dharma University.

[20] Marie.C. Tahalele and Victor. R. Pattipeilohy. 2014. The Effects of Hedonic Consumption and Positive EmotionsBehavior Purchase of Impulse at Alfa Supermarkets in Ambon City. Bencmark.Vol. 2 No.3.

[21] Mulianingrum, Wikartika. 2010. Impulse Buying on the Super T-Shirt Brand. Essay. Eleven University March.

[22] Oswari, Teddy., Reni Diah K., and Tristyanti Y. 2019, Marketing Research. Jakarta: Gunadarma.

[23] Rahmawati, Nurul Tri. "The Influence of Hedonic Shopping Value and Shopping Lifestyle on Impulse Buying with Positive Emotions as Mediation Variables". Yogyakarta State University.

[24] Riadi, Edi. (2016). Research Statistics (Manual Analysis and IBM SPSS). Edition 1. Yogyakarta: ANDI.

[25] Rosyida, Syafitri \& Anik Lestari Anjarwati. "The Influence of Store Atmosphere and Sales Promotion on Impulsive Purchasing with Positive Emotions as the Intervening 
Variable".

[26] Semuel, H. 2005. Environmental Response to Shopping as a Purchasing Stimulus. Journal of Management and Entrepreneurship. Vol. 7, No.2.

[27] Seo, J., Hathcote, JM and Sweaney, AL (2001). Casualwear shopping behavior of college men in Georgia, USA. Journal of Fashion Marketing and Management, 5 (No. 3), pp. 208-22.

[28] Setiadi, Nugroho J. 2008. Consumer Behavior Concepts and Implications for Marketing Strategy and Research. Jakarta: Prenada Media.

[29] Setiadi, I Made Willy \& I Gde Ketut Warmika. "The Influence of Fashion Involvement on Impulse Buying of Fashion Consumers Mediated by Positive Emotion in Denpasar City". Udayana University.

[30] Sugiyono, 2010. Research Methods, Bandung: CV Alfa Beta.

[31] Sugiyono. (2016). Quantitative Research Methods, Qualitative and R \& D. Bandung: PT Alphabet.

[32] Tirmizi, MA, Rehman, K. U and Saif, M. I, 2009. An Empirical Study of Consumer Impulse Buying Behavior in Local Markets. European Journal of Scientific Research. ISSN 1450-216X Vol. 28 No. 4 (2009) pp 552-553.

[33] Utami, Christina Whidya. 2010. Retail management, second edition. Jakarta: Salemba four.

[34] Wijanto, S. 2008. Structural Equation Modeling with Lisrel 8.8. Graha Ilmu, Yogyakarta.

[35] BOC "internet users in Indonesia" article accessed on May 7, 2019, https://www.boc.web.id/statistik-pengguna-digital-dan-internet-indonesia-2019/

[36] Lubis, Milladine 2014. "Indonesian Consumers are Starting to Love Online Shopping", Nielsen, accessed on 15 January 2018, fromhttp://www.nielsen.co./en/en/pressroom/2014/konsumen-indonesiamulai-menyukai-belanja-online.html 